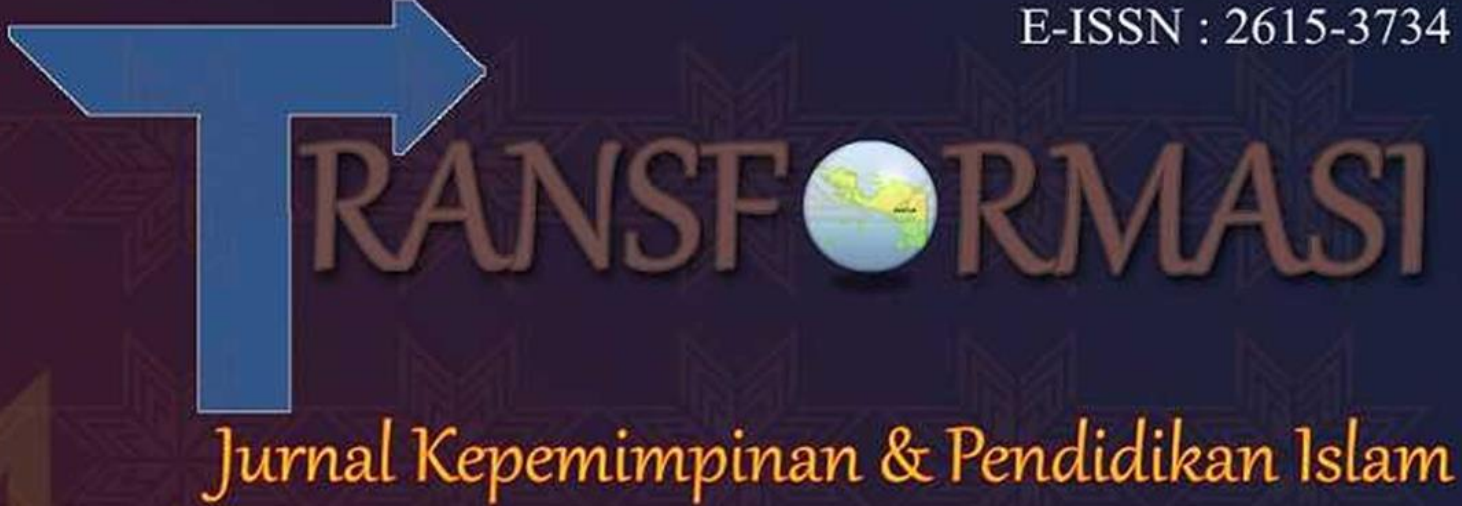

VOLUME 2 NOMOR 2 JUNI 2019

PRINSIP-PRINSIP PENGEMBANGAN TRANSFORMASI PENDIDIKAN MADRASAH TSANAWIYAH DI MAKASSAR

\section{Zain Hanafi}

PENDIDIKAN KARAKTER DALAM TRADISI KEAGAMAAN MASYARAKAT MUSLIM PAPUA BARAT

\section{Akramun Nisa}

STUDENTS' STRATEGIES IN ACADEMIC WRITING: A STUDY ON LEARNING STRATEGIES USED BY HIGH-ACHIEVEMENT STUDENTS AT STKIP MUHAMMADIYAH BONE

Syamsir Bin Ukka, Baso Jabu, Sukardi Weda 


\title{
STUDENTS' STRATEGIES IN ACADEMIC WRITING: A STUDY ON LEARNING STRATEGIES USED BY HIGH-ACHIEVEMENT STUDENTS AT STKIP MUHAMMADIYAH BONE
}

\author{
Syamsir Bin Ukka, Baso Jabu, Sukardi Weda
}

IAIN Fattahul Muluk Papua, Universitas Negeri Makassar (UNM), Universitas Negeri Makassar (UNM)

david_syam@hotmail.com, basojabu@gmail.com, sukardi.weda@unm.ac.id

\begin{abstract}
This research aimed to find out the strategies used by the high-achievement students in academic writing and to find out the lecturers' perception about the strategies applied by the students at STKIP Mubammadiyah Bone. This research is a descriptive qualitative research that applied two research questions. The data was collected from the subjects that consist of six students and one lecturer. The research subjects were chosen by purposive sampling technique. The researchers were the main instruments of the research and applied interview and taking research notes by using observation sheets. This research used interview and observation to collect the data. The writing class activities were observed and the respondents were interviewed. The results were analyzed descriptively. Based on the data analysis, it was found that students used different learning strategies in academic writing. Students $A$ and $C$ used cooperative learning strategy because they enjoyable in small group discussions before make decision while Students $B$ and E used mapping strategy who like follow the structured writing stage of writing. Student D used spider web strategy that refers to arrange the ideas more structured and Student F used collaborative learning strategy that student who like giving and asking help. The lecturer's perception indicated that students who learnt writing skill use different strategies based on their understanding level. The findings and conclusions noted that the learning strategies applied by the students in this research based on their achievement level and learning style. By these strategies, the students are capable to increase their writing skill by using the appropriate strategy.
\end{abstract}

Keywords: learning strategies, academic writing, writing strategies, perception 


\section{INTRODUCTION}

Academic writing is a challenge for non-native English speakers. It is very difficult for students who come from non-English culture, especially the Indonesian students who have a local language as their first language. Al Fadda (2011) stated that students face many problems in their academic writing, including those caused by distinguishing between spoken and written in the style of English textbook. These problems not only happen to the students at leading colleges but also found at the students of STKIP Muhammadiyah Bone. Based on the pre-observations and the data from English lectures at this institution, there are many problems still faced by students in writing such as grammar error and still did mistake in using phrase and so on. It showed from the students' results of writing assignment.

Therefore, in addressing the problem above, related parties such as schools and universities have to find out and employ learning strategies to develop students' skills in mastering English especially in writing skill. Duessen et al in Emadzadeh (2015) stated that educators have to use strategies to help their students learn academic content while learning to understand, speak, read, and write English. Effective strategies are a prerequisite to solve problems and make decisions appropriately. Making strategy is a greater action designed to achieve institutional goals supported by formal policies and management rules. Picard (2004) stated that the strategies are particular suggestions for obtaining knowledge about practicing teaching skills and several of activities are integrated.

A well-designed strategy will help achieve the highest level of effectiveness in achieving the goals while continuing to allow monitoring the environment to adapt the strategies required. Picard (2004) explained that strategies are things that teachers can do, alone or in collaboration either with the principal or with colleagues. The strategy presented does not intended to be comprehensive but they can serve as a starting point for developing other strategies. A certain strategy can be modified to meet the basic needs of learning. Therefore, the selection of strategies should also be appropriate for the level of development of students in the classroom. Students should take extra care in choosing the strategy that they will apply in the classroom with students who really have a basic knowledge about their mastery of the English language courses particularly academic writing skills or students with special needs.

This research was intended to answer the following questions: (1) what strategies are used by the high-achievement students in the academic writing at 
STKIP Muhammadiyah Bone? (2) How is the lecturers' perception about the strategies applied by the students at STKIP Muhammadiyah Bone?

\section{Writing Skill}

Some experts give different opinions about the writing definitions. Spratt, et al. (2005) declared that writing is a productive skill, which means students involves producing language rather than accept it. Very simply, we can say that writing involves communicating a message. To write a message and someone we need to communicate. Writing is a talent to form letters and words, and combines it to form of sentences to communicate a message.

Al Fadda (2011) stated that the academic writing is a product of mind because it is a mental and cognitive activity. Actionable view of writing as a mental and cognitive activity is the image of someone who works in a quiet environment.

On the other side, Carroll (1990) said that writing is one way to communicate not only with coeval, but also to next generations. The reason is writing gives a permanent evidence of information such as feelings, arguments, opinions, beliefs, explanations, theories, etc.

From experts' definitions, the writer concludes that writing is a productive skill that produces products of a mind. It is mental and cognitive activity such as feelings, ideas, and arguments on paper to convey meaning through text built. Writing may be regarded as a test of memory, language, and the ability to think for all that is written in the essay is the experience that exists in their minds and will be reading material for future generations.

Academic writing is a subject for students who study a language in colleges and universities where they learn English as foreign language. Bailey (2006) stated the students who are non-native speakers of English often consider the writing course is very challenging. Students have to do a variety assignment of writing all through their course. The students completed the writing tasks ender examination and or as coursework. The students are requested to do writing task depend on the kind of writing as the subject they are studying that mean the education course will be different tasks from different language art course.

According to Bailey, (2006) said that academic writing has four parts. There are writing processes, the writing elements, writing accuracy, and writing models. The writing processes and writing elements focus on key of writing skill and writing accuracy and models focus on revision and reference. 
Ur in Alawi (2011) stated that the writing purpose is the ideas expression that expresses the message to the reader. The most important writing aspect should arguably show the ideas themselves. This means that the authors have some purposes when they do writing. The writer should consider their writing purpose as will affect not only to the type of text they want to produce but also includes language that they use and the information they select.

In terms of theory of language learning, approach is divided into at least two points. The first is behaviorism approach. That is an approach which assumes that language can be learnt through the new habit formation. The second is cognitivism constructivism approach. That is an approach which emphasizes more on process of thinking. In addition, there are four general purposes in writing; to inform, to explain, to persuade, and to amuse reader.

\section{Learning Strategy}

Oxford in Zare (2012) stated that the students take learning strategy as the particular actions to make their learning easier, faster, more fun, more independent, more effective, and more transferable to latest situations. It is, indeed, a reflection of what the learners intend to do and the specific actions they can take.

In other side, Chamot (2004) stated that learning strategies are reflections and actions that individual or group use to reach the learning purpose. Comprehensive study has recognized students to use a various learning strategies of second or foreign languages and a smaller study has documented the effectiveness of helping fewer successful students to improve their achievement through learning strategy instruction.

According to experts' definitions above, we know that learning strategies are minds and actions, behaviors, procedures, or method that are taken and used by student to achieve the learning objectives. This is an operation or measures that used by learners to make the learning process easier, faster, fun, independent, and more effectively to new situations.

Rubin in Zare (2012) allocated efforts in the field of language learning strategy makes the difference between direct strategy and indirect strategies. Direct strategies consist of meta-cognitive strategies and cognitive strategies while indirect strategies consist of communicative strategies and social strategies. Three types of strategies can be used by students are learning strategies, 
TRANSFORMASI: Jurnal Kepemimpinan Dan Pendidikan Islam

Volume: 2 Nomor 2 Juni 2019

Pendidikan Karakter Dalam Tradisi Keagamaan H. 51-63

Syamsir

communication strategies, and social strategies that contribute directly or indirectly to language learning.

\section{Writing Strategies}

Okasha \& Hamdi, (2014) stated that writing strategies are manner of how to control the writing process to create a good organized creation of realize by high quality. The students used cognitive and meta-cognitive procedures to manage the writing production and to solve the problem while writing. Students should active when they are doing writing that means they are able to use some writing strategies in a flexible way to be planned writer. Strategic writing is a skill to observe and adjust writing during writing progression.

\section{METHOD}

\section{Design and Participants}

This research is under design of descriptive qualitative research. The participants of this research were chosen through purpossive sampling technique. The researcher focuses to interview six students from sixth semester of English Education program to find out what learning strategies they applied and one lecturer for his perception about learning strategies used by students in academic writing.

Table 1, Participants

\begin{tabular}{|c|c|c|c|c|c|}
\hline No & Name & Sex & Job & Course & Semester \\
\hline 1. & Student A & Female & Student & $\begin{array}{l}\text { English } \\
\text { Education } \\
\text { Program }\end{array}$ & Sixth \\
\hline 2. & Student B & Female & Student & $\begin{array}{l}\text { English } \\
\text { Education } \\
\text { Program }\end{array}$ & Sixth \\
\hline 3. & Student C & Male & Student & $\begin{array}{l}\text { English } \\
\text { Education } \\
\text { Program }\end{array}$ & Sixth \\
\hline 4. & Student D & Female & Student & $\begin{array}{l}\text { English } \\
\text { Education } \\
\text { Program }\end{array}$ & Sixth \\
\hline
\end{tabular}


TRANSFORMASI: Jurnal Kepemimpinan Dan Pendidikan Islam

Volume: 2 Nomor 2 Juni 2019

Pendidikan Karakter Dalam Tradisi Keagamaan ...., H. 51-63

Syamsir

\begin{tabular}{|c|c|c|c|c|c|}
\hline 5. & Student E & Male & Student & $\begin{array}{l}\text { English } \\
\text { Education } \\
\text { Program }\end{array}$ & Sixth \\
\hline 6. & Student F & Male & Student & $\begin{array}{l}\text { English } \\
\text { Education } \\
\text { Program }\end{array}$ & Sixth \\
\hline 7. & Teacher & Male & Lecturer & Writing & - \\
\hline
\end{tabular}

\section{Data Collection}

In collecting the data, the researcher used semi-structured interview to get the data about learning strategies applied by the students in academic writing. The researcher also interview the lecturers of writing skill to get their perceptions about the learning strategies that used by the students in learning writing.

The researcher used sheets of classroom observation note to conduct the observations. He observed the writing activities in the classroom when the writing class was going on.

\section{Data Analysis}

The data analysis performed trough certain techniques in accordance with the type and purpose of the data. The researcher divided the analyzing data in two sessions. They are the analysis of observation and the analysis of the interview.

First, the researcher coded the observation data into some different kinds of prompts based on the interaction happen during the writing process. Then reported and generated the data to tabulate number of each type of strategy that use in writing process.

Second, the data from interview analyzed through recorded and transcribed to get the precise and more accurate data. In transcribing the data, the researcher coded and substituted with pseudonyms the name of participants. Then, categorized the data based on the thematic analysis that became the main concern of this study about students' strategies in their writings.

At last, researcher classified or coded and categorized all of the data into pieces of data, group them into themes, then presented, and interpreted descriptively. 


\section{FINDINGS}

\section{A. Students' Strategies in the Academic Writing}

Writer found that the respondents said that writing skill is the most difficult one. In writing, the students have to think about many aspects before write something such as grammar, structure, and tenses. This forced the students to look for a good strategy to enable them to write effectively. It is deal to Student A statement that they must think all aspect what they want to write and what strategy to apply to make a good writing while Student F said that the difficulty of writing skill depend to the situation of learning such as formal or informal situation.

The lecturer gave some strategies in teaching writing to help students in completing their writing exercise. The researcher found in the classroom observation, the students learn in group and the lecturer explain them step by step how to develop sentences to be a good paragraph. This deals to the students' explanation in interview. Student A stated the teacher gives them the steps how to make a paragraph and asks the students to make a sentence and thinking about the topic and main idea. The teacher also used variety-teaching strategy like Student C statement "variation, one of them is game learning like Team Games Tournament that students are given a game in form cooperative learning"

Students also combine the strategies for facilitating and guiding them to complete their writing task easily and affectively. Observation data supported it when researcher notes that some students open the internet on their computer. They can organize sentences into a paragraph freely without thinking about the grammar mistake that will arise in their writing process. One of the students' statements is that "I combine the strategy that given by the teacher with the strategy I got from internet. These make me easy to understand how to write".

The researcher also found that the students used a difference writing strategy when they did writing task in-group and individual one. Most of them stated that grouping was better than individual one. Just student B said that individual learning is better like in her statement "Base of my mind I like does writing exercise alone because sometimes my thoughts and my friends' thoughts were different and I preferred to do myself".

In writing process, researcher also found that some students use their first language before they translate it into English. In pre-writing stage where the students write words or phrases, the students wrote in their first language and 
then develop them to sentences before they translate it into English. They used translation tool before they did process of editing.

Table 2 shows the learning strategies that applied by all students when they learn writing skill especially making a paragraph. Although all students used different strategies but researcher found that in the class of writing most of the writing stage that they have done were similar because they usually worked in grouping such as the lecturer used cooperative learning in teaching strategy.

Table 2, Students' Learning Strategies

\begin{tabular}{lll}
\hline No. & Respondent & Strategy \\
\hline $\mathbf{1}$ & Student A & Cooperative learning strategy \\
$\mathbf{2}$ & Student B & Mapping strategy \\
$\mathbf{3}$ & Student C & Cooperative learning strategy \\
$\mathbf{4}$ & Student D & Spider web strategy \\
$\mathbf{5}$ & Student E & Mapping strategy \\
$\mathbf{6}$ & Student F & Collaborative learning strategy \\
\hline
\end{tabular}

\section{B. Lecturer's perception about the strategies applied by the students}

The lecturer said that students have to find some strategies to help them in writing. This was necessary because the students have different writing abilities in the class like his statement "I think it helps them very much because the students have different level of understanding. So, it is important to them to find a strategy that suitable for their level'. From this statement, we know that students need to use a strategy that suitable to their understanding level. The lecturer also has to use various strategies in teaching writing like collaborative learning strategy where the students can help each other and work together in doing their writing task

Students' strategy was good and effective because they combined and applied the strategy from another resource. In this case, the lecturer guided the students to combine the strategies correctly. Besides that, the lecturer suggested them to find other strategies to get more knowledge about how to write effectively.

The lecturer's strategy was easier to understand because he gave complete explanation systematically to the students as finding in classroom observation. It is clear by his statement "I try to find sometbing easier steps in writing process. I explain systematically how to write effectively. I do not give students to write one paragraph but I give them sentence by sentence". 
There are students used a translator tool in their writing process. According to the students, this tool helped them to do their writing assignment. They can understand all steps in writing process what they have written. However, the lecturer disagrees with the students' statements and gives different opinions. The lecturer said that he do not agree with the student use machine translator because some of the students always want to relay to machine which do not improve their writing skill by themselves but only rely on the machine.

When the students used a translator tool, it means that the students used bilingual in their writing process. Firstly, they used their first language in writing sentence, and the secondly they used a translator tool to translate it into English. The lecturer gave perception that this was a good manner but not effective in improving their writing ability such as his statement "I think this is a good way but I think it is not effective for the students. The result of the task is good but the ability for the students does not have improvement".

\section{DISCUSSIONS}

\section{A. Student's Strategies in the Academic Writing}

The main findings of this thesis showed that the students' strategies are various according to their understanding level. In general, students learn writing in cooperative learning method as like as teaching method used by the lecturer in the writing classroom. They learned freely with students centered method. It gave them freedom to find and use other strategies that they think were easy and suitable with their achievement level.

Students said that the writing skill was the most difficult skill that must to master. Based on the observation data, most of the students follow the standard procedure of writing process but some of them not followed all stage. They gave their reason that writing skill have to think many aspect of sentence structure before they write something such as grammar and vocabulary.

The students gave the reasons about they have used different writing strategy when they did writing exercise in the classroom and at the home as they did homework writing task. In the classroom, they have a lecturer and the classmate who can help them when they faced the problem in writing process but at the home, they have to do it alone.

In the main activity of the writing process, the lecturer gave students assignment in timetable form. The lecturer just gives students some topic 
sentences and they have to make one or three supporting sentences. This made students used mapping strategy in their writing assignment. Like Student B and E used this strategy. This strategy also similar with the spider web strategy such as the student $\mathrm{D}$ used, this made them easier to write sentence by sentence to form a paragraph effectively. They like this strategy because it more structured in writing stages. It deals to students who weak in formulating ideas based on the primacy.

The other students used free writing strategy although the strategy applied in cooperative learning strategy like Student A and C did. They said that they wrote without thinking about the grammar rule. It made them more concentrate to write ideas related to the topic or theme freely. They also be easier created more idea then they have to think the grammar rule first. The students just check the grammar in editing stage. They also can ask help from the group member or sometime to the lecturer if available.

By working in cooperative learning strategy is which teacher divided the students into small group that gave them chance to share and help each other. This strategy is so called collaborative learning strategy such as did by student F. This strategy deals to students who have lack in vocabularies and grammar rules. They need help from the other members of the group in learning process such as smart student could help the weaker one. It could make them easier in finding and arranging the ideas to make paragraph. The students also can resolve the problem that they faced in writing process such as correcting the grammar error together.

The other things, most of the students also used their first language before they translate it into English. They use translation tool in writing process. They said that they involved their first language in a step of writing process that can help them more understand what they have written. This was useful for them who have lack vocabulary. The students use their first language when they develop the words of phrases in the free writing stage where the sentences first time created. However, the students had to translate it into English form before they did the first draft in the writing or revising stage.

\section{B. Lecturer's perception about the strategies applied by the students}

The lecturer gave them teaching strategy that easy to understand because of the students have different level of understanding. It meant that lecturer just gave the students some topic sentences and they requested student to give some 
supporting sentences instead. From the simple teaching strategy, the lecturer give the students chance to find other strategy from other resources related to their ability to facilitate them in writing process.

By combining the strategies, the students can resolve the problem that they faced in writing procedure that made them still confuse. According to the interview with lecturer said that not all strategies were suitable to all students because they had different learning style and understanding level. Therefore, the students have different understanding level need different strategy in learning writing.

Talking about the students used their first language in the writing process; the lecturer said that it was good way but does not effective to the students' achievement in writing ability. They only relay on to the translator tool rather than to improve their writing achievement by themselves. It because the translator tool usually has disarrangement of structure and incorrect grammar, they still faced a problem especially in grammar mistake. This case was not exercised the students to improve their grammar understanding. They just get instantly from the translator tool without know how to form the rule of grammar.

\section{CONCLUSIONS}

Based on the research findings and discussion, the researcher concludes the result of this research as follows:

1. Student A and C applied Cooperative Learning Strategy. This strategy refers to instructional methods in which the students work in-group to have small discussions before makes decision. They applied this strategy because it gives them chance to exchange their ideas and choose the right ideas together with the group member. This strategy is more communicative and fun activities.

2. Student B and E applied Mapping Strategy. They used this strategy because it was structured strategy, which shows the relationship of ideas in writing stage in procedure of writing process. It is means they are easier and have sorter time to arrange the sentences into a good paragraph.

3. Student D applied Spider Web Strategy. This strategy is similar with mapping strategy. It makes him easier arranged the words or phrases and ideas to make sentences structured on spider web or table form. 
4. Student F applied Collaborative Learning Strategy. The strategy is also similar with the cooperative learning strategy. He likes working in the small group for sharing and discussing the ideas. He used this strategy because need help from group member to do their task in the group. It means students could give helps to weak students in writing.

5. Based on the lecturer's perception, it was important to choose the suitable strategy with the students' understanding level and learning style in academic writing. Teaching or learning strategies that suitable with students' understanding level was a key in writing skill improvement.

\section{SUGGESTION}

Based on the conclusion above, the researcher addresses the following suggestion and recommendation:

1. The teacher should use teaching strategy that suitable to the students' learning strategies that have different style and understanding level. The teacher also has to guide the students to find a good strategy for writing skill improvement.

2. The students who want to improve their writing skill should apply the suitable strategy based on their understanding level.

3. The further researchers should investigate the effectiveness of appropriate learning strategies.

\section{REFERENCES}

Al Fadda, H. 2011. Difficulties in Academic Writing: From the Perspective of King Saud University Postgraduate Students. English Language Teaching, (Online), Vol. 3, No. 3, 123, (http://www.ccsenet.org/journal/index.php/elt/article/viewFile/15272 /10336, Retrieved on $16^{\text {th }}$ January 2016).

Alawi, F. F. 2011. Improving Students' Ability in Writing Descriptive Text Using Clustering Technique. Unpublished Action Research). Jakarta: Faculty of Tarbiah and Teachers Training Syarif Hidayatullah State Islamic Unibersity.

Bailey, S., 2006. Academic Writing:A Handbook for International Students (2 ${ }^{\text {nd }}$ 
TRANSFORMASI: Jurnal Kepemimpinan Dan Pendidikan Islam

Volume: 2 Nomor 2 Juni 2019

Pendidikan Karakter Dalam Tradisi Keagamaan H. 51-63

Syamsir

Edition).London: Routledge Taylor \& Francis Group.

Carroll, R. T. 1990. Student Success Guide: Writing Skills.Ebook.(Online), (http://skepdic.com/refuge/writingskills.pdf, $16^{\text {th }}$ October 2015).

Chamot, A. U. 2004. Issues in Language Learning Strategy Research and Teaching. Electronic Journal of Foreign Language Teaching, (Online) Vol. 1, No. 1,14-26 (http://e-flt.nus.edu.sg/, Retrieved on $16^{\text {th }}$ October 2015)

Emadzadeh, Jenna N. 2015. Effective Practices for Developing Academic Language and Writing Skills in English Language Learners in the Elementary School Setting. Master's Theses and Capstone Projects, Paper 158. California: Dominican University of California (http://scholar.dominican.edu/masters-theses, Retrieved on $16^{\text {th }}$ October 2015)

Okasha, M. A. \& Hamdi, S. A. 2014. Using Strategic Writing Techniques for Promoting EFL Writing Skills and Attitudes. Journal of Language Teaching and Research,5(3), 674-681.

Picard, C. 2004. Strategies for Effective Teaching in the Twenty-First Century. Louisiana: State Superintendent of Education. (http://files.eric.ed.gov/fulltext/ED497756.pdf, Downloaded on $16^{\text {th }}$ October 2015)

Spratt, M., Pulverness, A. \& Williams M. 2005. The TKT Teaching Knowledge Test Course. UK: Cambridge University Press.

Zare, P. 2012. Language Learning Strategies Among EFL/ESL Learners: A Review of Literature. International Journal of Humanities and Social Science, (Online) Vol. $\quad 2, \quad$ No. (http://www.ijhssnet.com/journals/Vol_2_No_5_March_2012/20.pdf, Retrieved on $24^{\text {th }}$ February 2016) 